Bangladesh J. Bot. 47(4): 911-920, 2018 (December)

\title{
PHYTOCHEMICAL COMPOUNDS OF LILIUM LEDEBOURII BIOSS USING BULB EXPLANTS
}

\author{
Sina Ghanbari ${ }^{*}$, Barat Ali FaKheri ANd Nafiseh Mahdinezhad \\ Department of Plant Breeding and Biotechnology, Faculty of Agriculture, \\ University of Zabol, Zabol, Iran

\begin{abstract}
Keywords: Lilium ledebourii Bioss, Superoxide dismutase, Peroxidase, Flavonoid, Antioxidant, DPPH, Total Phenol.
\end{abstract}

\begin{abstract}
Lilium ledebourii Bioss is a wild species of Lilium, which grows naturally in Damash Mountains of Roodbar, Iran. Secondary metabolite synthesis in plants is one of the most important defensive mechanisms applied against various pathogens, and the quality and quantity of those materials depend on the species diversity, organs, habitat conditions, and different extraction methods. In this study, phytochemical compounds were measured quantitatively and qualitatively. Results showed the existence of secondary metabolites in the regenerated plants. Phenolic content was $5.198 \pm 0.17 \mathrm{mg}$ in each extract. Radical trapping of the diphenyl-picryl hydrazyl test was $3.24 \pm 0.52 \mathrm{mg} / \mathrm{ml}$. Antioxidant activity based on reduced iron was $25.88 \pm 1.47 \mathrm{mmol} \mathrm{fe} \mathrm{e}^{+2} / \mathrm{g}$ DW. Flavonoid content of $L$. ledebourii Bioss was $0.78 \pm 0.07 \mathrm{mgRE} / \mathrm{G}$. Peroxidase and superoxide dismutase's enzymes activity in L. ledebourii Bioss was low. Also, in this study, the combination of saponin, cardiac glycosides, Steroids, Alkaloids and Terpenoid was seen qualitative in the $L$. ledebourii Bioss.
\end{abstract}

\section{Introduction}

Nature is a rich source of medical metabolites and some of them are found in plants. Extracts, which are rich in flavonoid metabolites, through decreasing oxidative stress, protect cells (Maber and Hanneken 2005). Phenols and polyphenols are found in many foods and have great antioxidant effects (Bouayed et al. 2011). Extracts, which are rich in flavonoid metabolites, through decreasing oxidative stress, protect cells (Maber and Hanneken 2005). Phenols and polyphenols are found in many foods and have great antioxidant effects (Bouayed et al. 2011). In developing countries, due to the side effects of chemical medicines, use of herbal plants in treating various diseases and use of natural antioxidants in food industries have been received much attention, and studies are increasingly being conducted on the extraction of active biological metabolites of plants (Asghari and Mazaheri-tehrani 2010). Plant value is most important because of the production and performance of its secondary metabolites (Akinmoladun et al.2007), and some of the most important metabolites are alkaloids, flavonoids, tannins, saponins, terpenoid and phenolic compounds (Edeoga et al. 2005). As plants are important source of antioxidants, the studies in this field have been increased gradually. Those plants which are rich in antioxidant metabolites can protect cells from oxidative dangers (Kumaran and Karunakaran 2006). Since the different metabolites act based on the different mechanisms, it is obvious that only one method cannot provide a comprehensive prediction of the effects of all involved issues of antioxidant characteristics (Pellegrini et al. 2000).

Some of the well-known methods of measuring antioxidative features, are radical entrapping of 1,1-diphenyl-2-2picrylhydralise (DPPH, based on the hydrogen endowing ability of extract) (Miliauskas et al. 2004), the study of inhibition of lipoic acid oxidation (BCB), and the evaluation

*Author for correspondence: <sina_qanbari@yahoo.com> or <sina.qanbari@gmail.com>. ${ }^{1}$ Plant Bank, Iranian Biological Resource Center (IBRC), ACECR, Tehran, Iran 
of antioxidant activity of extracts is based on the reduction ability of divalent iron (Benzie and Strain 1999). In fact it shows an estimation of antioxidative characteristics of soluble metabolites in water. FRAP method evaluates the antioxidative activity of extracts based on iron reduction ability (Deepa et al. (2007). It also shows an estimation of antioxidative characteristics of soluble metabolites in water. Gardner et al. (2000) showed that ascorbic acid content has a direct relationship with antioxidant metabolites of extract in FRAP method. The refining activity of existing free radicals in the extract is studied by DPPH method, and Velioglu et al. (1998) reported that it had a linear relationship with existing phenolic and flavonoid metabolites in the plant. Phenolic metabolites are a group of compounds which exist in all plants such as fruits, vegetables, and cereals. These compounds are secondary metabolites of plants (Taiz and Zeiger 2002). Naturally, about 8000 different phenolic compounds with the characteristics such as involvement in making NDF, the defensive mechanism of the plant, and fruit characteristics like color, flavor, taste, exist in plants. In addition, phenolic compounds are considered as indexes for identifying physiological stages during fruit growth (Macheix et al.1990). The content of plant secondary metabolites such as, pure flavonoids, and their antioxidative characteristics depends on the different factors such as weather, species, extraction method, and antioxidant measuring method (Kumar and Neelam 2006). Flavonoids and other phenolic compounds are widespread in plants and previously various biological activities of these compounds such as antioxidative, antibacterial, and anti-inflammatory characteristics have been studied by (Jamshid et al. (2010).

Environmental tensions through increasing production of different types of active oxygen and protein-DNA, induce some harms to vital bio molecules such as lipids. In order to decrease negative effects of various active oxygens in cells, plant's cells apply different antioxidative systems which include an enzyme and non-enzyme factors such as superoxide dismutases (SOD), catalase (CAT), and peroxidase (POD) (Singh et al. 1994). Enzyme activities are the most important factors in plant resistance to environmental conditions. Superoxide dismutases as the key antioxidant mainly in the cytosol, chloroplast, mitochondria, and peroxisome attracted much attention of the scientists as it catalyzes radical superoxidase to hydrogen peroxidase (Singh et al. 1994). Therefore, SOD is considered as one of the important components of the defensive mechanism.

Lilium ledebourii Bioss is a species of Lilium family and it is an herbaceous and permanent plant. This plant has uncovered bulbs of 50 to $150 \mathrm{~cm}$ height. It has linear and dagger-like leaves which are 10 to $24 \mathrm{~cm}$ long and 1 to $2 \mathrm{~cm}$ wide. It has white flowers with long peduncles which are $13 \mathrm{~cm}$ long, and there are 2 to 25 of them in each plant (Zhou et al. 2008). This plant which is the rarest species of Lilium grows in few areas of Iran such as Ardebil, Mazandaran, and Gilan provinces. In addition to Iran, it only grows in Lankaran in the Azerbaijan Republic (Rechinger 1989, Zhou et al. 2008). Although few studies have been done on L. ledebourii Bioss (Azadi 2003, Padasht 2005, Azadi and Khosh-Khui 2007), bioactive compounds of this plant are unknown. So, the aim of this study was to evaluate the phytochemical compounds of this native plant.

\section{Materials and Methods}

Lilium ledebourii Bioss bulbs were collected from Damash Mountains and were sent to the phytochemical laboratory of Iranian Biological Resource Center. For the preparation of Hydroalcoholic extracts $2 \mathrm{~g}$ of plant samples were dried by oven dry and freeze dry methods (Bernard et al. 2014) and shaken for $24 \mathrm{hrs}$ at $30^{\circ} \mathrm{C}$ with $150 \mathrm{rpm}$ in hydroalcoholic solution, and then filtrated. Finally, extracts were prepared for non-enzyme tests. 
During Enzyme extraction in order to obtain cellular extract to study superoxide dismutase (SOD), peroxidase and catalase enzymes, about $1 \mathrm{~g}$ of fresh plant bulb were put into porcelain mortar and after adding liquid nitrogen, it was ground completely. Ground sample 0.5 gr was weighted and mixed with the buffer. Based on studied enzyme types, the enzyme extraction buffer was prepared. To produce extract one $\mathrm{ml}$ of intended buffer was added in the micro tube and was centrifuged in $4^{\circ} \mathrm{C}$ with $125000 \mathrm{rpm}$ for $20 \mathrm{~min}$.

To extract superoxide dismutase SOD at $4^{\circ} \mathrm{C}, 50 \mathrm{mM}$ of potassium phosphate buffer with 7 $\mathrm{pH}$ and $0.5 \mathrm{mM}$ EDTA was used. SOD activity was measured using spectrophotometry. One ml of reaction solution contains $0.1 \mathrm{mM}$ EDTA, $50 \mathrm{mM}$ phosphate buffer, $13 \mathrm{mM}$ methionine, $75 \mu \mathrm{M}$ NBT, and $0.21 \mathrm{ml}$ molar riboflavin and enzyme supernatant. Covets containing reaction solution while were softly shaken for 15 min were put in front of inflorescence light (2 light bulbs with 250-watt inflorescence) and then sample absorption was read at $560 \mathrm{~nm}$ wavelength. In order to study enzyme activity, along with sample blank covets, control covets were used which contained blank cell, and similar control of sample cell. It should be mentioned that control cell along with samples was putted at the light and its wavelength was read as $560 \mathrm{~nm}$, and blank cell putted in darkness. The activity of each SOD includes an amount of enzyme which is necessary for $50 \%$ reduction inhibition of phytochemical NBT under measurement condition (Dhindsa et al. 1980).

Extraction buffer for peroxidase (POD) enzyme was $50 \mathrm{mM}$ potassium phosphate buffer with $7 \mathrm{pH}$ including 0.5 EDTA and was held at $4^{\circ} \mathrm{C}$ environments. POD activity was studied for one min in a reactive solution $(1 \mathrm{~m} / \mathrm{l})$ including $475 \mu \mathrm{l}$ guaiacol $475 \mu \mathrm{l}$ of $100 \mathrm{mM}$ hydrogen peroxidase, and $50 \mu \mathrm{l}$ of extracted enzymatic supernatant and was read against blank cell including all materials except enzyme sample. POD activity was measurable through following absorption changes in $470 \mathrm{~nm}$ wavelength, which is the result of guaiacol oxidation (Polle et al. 1994)

To extract catalase (CAT) at $4^{\circ} \mathrm{C}$ from $50 \mathrm{mM}$ potassium phosphate, the buffer including $1 \mathrm{mM}$ EDTA and 2\% PVPP was used. Catalase enzyme activity after decreasing $\mathrm{H}_{2} \mathrm{O}_{2}$ absorption determined with $39.4 \mathrm{mM} / \mathrm{cm}$ extinction coefficient for $2 \mathrm{~min}$ at $240 \mathrm{~nm}$. It should be noted that some minor changes were applied in the mentioned method. One $\mathrm{mM}$ of reactive solution for determining CAT activity includes $10 \mathrm{mM}$ hydrogen peroxidase, $25 \mathrm{mM}$ phosphate buffer, 0.1 $\mathrm{mM}$ EDTA with $7 \mathrm{pH}$. Every level of catalase enzyme is definable in form of the content of enzyme, which decomposes one $\mathrm{mM} \mathrm{H}_{2} \mathrm{O}_{2}$ in one min in testing condition (Rigo and Rotilio 1977).

The basis of reduction power (FRAP) method is on converting $\mathrm{fe}^{3+}-\mathrm{TPTZ}$ to $\mathrm{fe}^{2+}-\mathrm{TPTZ}$ at the presence of an antioxidant. FRAP solution contains $0.3 \mathrm{mM}$ buffer acetate (3.6 PH), TPTZ solution in $40 \mathrm{mM}$ HCL and $20 \mathrm{mM}$ solution of iron chloride (III) with 1:1:10 sequence. FRAP should be prepared freshly. In this method $100 \mu \mathrm{l}$ of diluted extract with $1.4 \mathrm{ml}$ of FRAP was mixed and after $15 \mathrm{~min}$, the absorption in $593 \mathrm{~nm}$ wavelength was read (Benzie and Strain 1999).

Total phenolic content in all samples was measured in the presence of folin-ciocalteu and then a standard graph with different concentrations of galic acid (0.01-0.05 mg/l) was drawn (Fig. 1). Some different concentrations which were different for various species were applied in order to obtain a linear range of each sample. For this purpose $500 \mu \mathrm{l}$ of diluted extract were mixed with $500 \mu \mathrm{l}$ of folin-ciocalteu, and after $3 \mathrm{~min}, 500 \mu \mathrm{l}$ of 0.01 sodium carbonate were added. Finally, samples were put in darkness for two hrs at room temperature, and then the absorbance was read at $765 \mathrm{~nm}$ wavelengths. Results were presented in the form of mg GAE/g DW (Fig. 1). One important point in measuring the total phenolic content is the production of air bubbles in the presence of folin which interferes in absorbance, so before reading absorbance levels, air bubbles should be removed by using vortex (Spanos and Wrolstad 1990). 


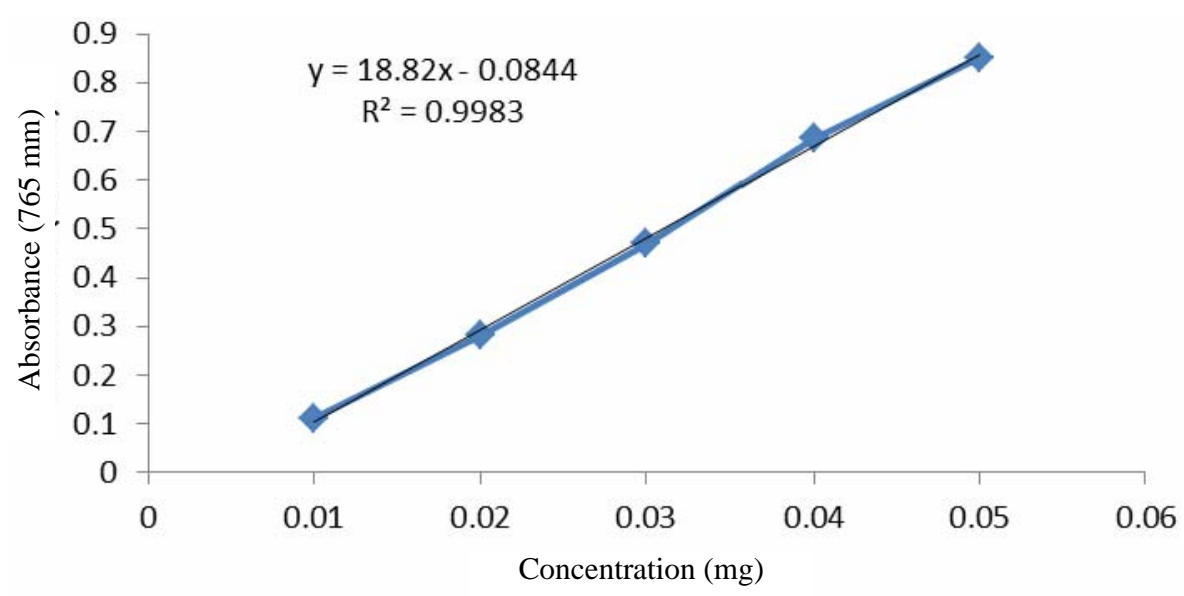

Fig. 1. Calibration curve for galic acid standards to measure total phenol.

Total flavonoid content was measured using aluminum chloride. The solution contains $300 \mu \mathrm{l}$ of diluted solution, $1.6 \mathrm{ml}$ water, and $100 \mu \mathrm{l}$ of 0.05 sodium nitrate. After 6 min, $150 \mu \mathrm{l}$ of $10 \%$ aluminum chloride was added. Next, after $5 \mathrm{~min}, 0.6 \mathrm{ml}$ of $1 \mathrm{M}$ sodium hydroxide and $250 \mu \mathrm{l}$ water were added and mixed completely by vortex. Then, the absorbance at $510 \mathrm{~nm}$ wavelength was read immediately. Standard graph with different routine concentrations (10-100 mg/l) was drawn and obtained results were presented in form of mg RE/g DW (Hosu et al. 2014).

In Inhibitory activity of DPPH free radicals method used for cleansing activity of DPPH radical was studied. The method is based on decreasing DPPH solution at the presence of hydrogen reducing antioxidants. The $300 \mu \mathrm{l}$ of $1 \mathrm{mM}$ DPPH were mixed into $100 \mu$ lof diluted sample and reached to their final volume of $2 \mathrm{ml}$ by the use of methanol. After putting for $30 \mathrm{~min}$ in darkness, absorption at $517 \mathrm{~nm}$ wavelength was read (Sanchez-Moreno et al. 1998)

Methods used for the quality analysis of secondary compounds namely, tannin, saponin, cardiac glycosides, terpenoid, alkaloids and steroids are as follows:

Tanin: $0.5 \mathrm{~g}$ of powdered plant was poured into $20 \mathrm{ml}$ of diluted water and warmed indirectly. Then the solution was filtrated and finally, some drops of ferric chloride III $(0.1 \%)$ were added to the extract. Development of brownish green and dark blue colors showed the presence of catechin tannin and pyrogallol tannin (Krishnaiah et al. 2009).

Saponin: Two grams of plant sample were boiled in $30 \mathrm{ml}$ of diluted water in Bon Mary method (Rouhi-Boroujeni et al. 2016) and then it was filtrated. Filtrated samples (10 ml) were added to $5 \mathrm{ml}$ of diluted water in a test tube and then the tube was shaken rapidly for about $1 \mathrm{~min}$ until stable foam produced. Then the produced foam was combined with three drops of olive oil. Emulsion (oil in water) and stable foam are representatives of saponin presence in plant extract (Krishniah et al. 2009).

Cardiac glycosides: One $\mathrm{ml}$ of dense sulfuric acid was poured into a test tube and set aside. Then $5 \mathrm{ml}$ of diluted watery extract and $2 \mathrm{ml}$ of acetic acid and one drop of ferric chloride were mixed together in another test tube. Then the content of the second tube was added to the first in such a way that dense sulfuric acid remains at the bottom. If the plant sample includes cardiac glycosides, then brown loops will appear (Krishniah et al. 2009). 
Terpenoid: Five ml of diluted watery extract was combined with $2 \mathrm{ml}$ of chloroform in a test tube and then they were added to $3 \mathrm{ml}$ of dense sulfuric acid to be mixed. Appearance of reddish brown layer shows the presence of terpenoid compounds in plant extract (Krishniah et al. 2009).

Alkaloids: Two g of the powdered plant was extracted with $8 \mathrm{ml}$ of chloroform and $10 \mathrm{ml}$ of ammonia chloroform solution was added. Then the solution was diluted and was transferred to a test tube. Sulfuric acid amounting $0.5 \mathrm{ml}$ (2 normal) was added to test tube and was shaken well. Finally, 3 drops of Mayer reagent were added. Milk like sediment shows the alkaloids in plant sample (Parekh and Chanda 2007)

Steroids: $200 \mathrm{mg}$ of plant samples were extracted with $10 \mathrm{mg}$ of chloroform. The solution was filtrated and $2 \mathrm{ml}$ of dense sulfuric acid sample was slowly added to $2 \mathrm{ml}$ of acetum anhydrate and $2 \mathrm{ml}$ of dense sulfuric acid. Blue-green loop shows steroids in the extract (Parekh and Chanda 2007).

\section{Results and Discussion}

Analysis of Phytochemical metabolites in L. ledbourii Bioss showed the activity of superoxide dismutases, peroxidase, antioxidants, phenolic compounds and flavonoid but no catalase (Table 1).

Table 1. Results of phytochemical metabolites in $L$. ledebourii Bioss.

\begin{tabular}{lcccccc}
\hline Plant & $\begin{array}{c}\text { Superoxide } \\
\text { dismutases }\end{array}$ & Peroxidase & Catalase & Antioxidants & $\begin{array}{c}\text { Phenolic } \\
\text { compounds }\end{array}$ & Flavonoid \\
\hline L. ledebourii & $*$ & $*$ & $*$ & $*$ & $*$ \\
\hline$*$ Plant secondary compounds & & & & & \\
\hline
\end{tabular}

The activities of superoxide dismutase and peroxidase enzymes were $13.82 \pm 0.74$ and $0.033 \pm$ $0.002 \mu \mathrm{M} / \mathrm{min}$, respectively (Table 2). Which shows that the activity of these enzymes in the bulb of $L$. ledebourii Bioss was low.

Table 2. Analysis of enzyme tests in L. ledebourii Bioss.

\begin{tabular}{rccc}
\hline Explant & SOD $(\mu \mathrm{M} / \mathrm{min})$ & POD $(\mu \mathrm{M} / \mathrm{min})$ & CAT $(\mu \mathrm{M} / \mathrm{min})$ \\
\hline Bulb & $13.82 \pm 0.74$ & $0.033 \pm 0.002$ & - \\
\hline
\end{tabular}

SOD $=$ Superoxide dismutases, $\mathrm{POD}=$ Peroxidase, $\mathrm{CAT}=$ Catalase .

Superoxide dismutase (SOD) plays a protective role in plants. SOD is antioxidative which catalases more active superoxide anions and converts them to oxygen and less active types of hydrogen peroxidase. SOD causes stability of cell membrane of plants during drought (Jose et al. 1999). Plant peroxidases, which are widely spread enzymes in organic plants, play important role in antioxidative defensive system of the cell and detoxificate reactive oxygen species. PODs protect the cell against toxic amounts of $\mathrm{H}_{2} \mathrm{O}_{2}$ (Parida and Das 2005). No activity was observed for catalase in this plants (Table 2). Catalase enzyme protects cells against hydrogen peroxidase. and is necessary for some cells under the natural conditions. It plays an important role in resistance to oxidative stress in adoptive reactions of cells (Fridovich 1995). One important method for losing $\mathrm{H}_{2} \mathrm{O}_{2}$ is peroxidase. This enzyme which is found in all over the cell has more combining affinity to $\mathrm{H}_{2} \mathrm{O}_{2}$ than catalase (Jimnez et al. 1997). Plants can identify environmental 
stresses and react to them. Like to other organisms, they activate radicals in reaction to biotic and abiotic stresses. In plants, producing reactive oxygen species (ROS) is for their adaptability and tolerance to different biotic and abiotic stresses. In this point of view, the activity of enzymes such as catalase (CAT), peroxidase (POD), and superoxide dismutases (SOD) thereby neutralize the activity of produced ROS in cells. Also, producing ROS in plant cells causes stimulations and increased activity of referred enzymes (Dat et al. 2000).

Flavonoid antioxidant activity in L. ledebourii Bioss based on freeze and oven dry methods was $0.78 \pm 0.07$ and $0.42 \pm 0.02 \mathrm{mg} \mathrm{RE} / \mathrm{g} \mathrm{DW}$, respectively (Table 3). The value of $0.78 \pm 0.07$ $\mathrm{mg} \mathrm{RE} / \mathrm{g}$ is less than Flavonoid compounds (41.34 mgRE. ${ }^{-1} \mathrm{DW}$ ) reported by Jin et al. 2012. The best method for drying non-enzymatic tests is freeze dry method. Flavonoids are a big group of a phenol compound with low molecular weight whose basic skeleton is formed by three benzene chains and a hydroxyl group. Mint (Mentha) extract has many phenol and flavonoid compounds and shows a good antioxidative activity (Sweetie et al. 2007).

FRAP method which studies the anti oxidative activity of extract based on iron rehabilitation ability, in fact, shows an estimation of antioxidative characteristics of soluble metabolites in water (Deepa et al. 2007). Enzymes are a group of proteins, which plays an activating role in the main metabolic pathway of plants. FARP antioxidant activity in L. ledebourii Bioss explants, based on freeze dry and oven dry methods was $25.88 \pm 1.48$ and $7.79 \pm 0.48 \mu \mathrm{M} \mathrm{fe} \mathrm{e}^{2+} / \mathrm{g} \mathrm{DW}$, respectively (Table 3). FRAP method which studies the anti oxidative activity of extract based on iron rehabilitation ability, in fact, shows an estimation of antioxidative characteristics of soluble metabolites in water (Deepa et al. 2007). Enzymes are a group of proteins, which play activating role in the main metabolic pathway of plants.

The antioxidative defensive system is active in all growth steps of plants. The acts of these antioxidants differ, and their change depends on some factors such as maturity, weather, used parts of plants, harvest conditions (Mejia et al. 1988). During plant growth, phytochemical changes affect their antioxidative activity and influence the quality of different fruits and vegetables in particular periods of time (Conforti et al. 2007). Strong ant oxidative activity of extracts is related to the high levels of existing phenols and flavonoids in extracts (Shukla et al. 2009, Sun et al. 2011).

DPPH is a free radical with nitrogen as its central atom, which changes its color from purple to yellow when it is rehabilitee and is converted to DPPH-H stable molecule. DPPH radical own 515 to $528 \mathrm{~nm}$ absorption level, but as rehabilitee by an antioxidant, its absorption lessens. The antioxidative activity of samples appears in the disappearance of purple and final emerging yellow. This reaction is performed rapidly (Khalili and Ebrahimzadeh 2015). Trapping activity of DPPH free radicals based on freeze dry method was $3.24 \pm 0.52 \mathrm{mg} / \mathrm{ml}$ while trapping activity of $\mathrm{DPPH}$ free radical in L. concolor was $4.531 \mathrm{TE} \mu \mathrm{M} / \mathrm{g}$ (Jin et al. 2012). Thus, trapping activity of DPPH free radical in L. ledebourii Bioss is lower than $L$. concolor and this is due to the low amount of phenolic compounds in L. ledebourii Bioss than $L$. concolor. DPPH is a stable free radical with nitrogen as the central atom which changes its color through reduction and converting 2, 2 diphenyl-1-picrylhydrazyl color from purple to yellow. DPPH in L. ledebourii Bioss explants using freeze and oven dry methods was $3.24 \pm 0.52$ and $11.27 \pm 0.97 \mathrm{mg} / \mathrm{ml}$, respectively (Table 3). Inhibitory activity of DPPH free radicals in plant extracts depends on the density and as density increases, inhibitory effect exceeds too (Shukla et al. 2009). Compositions in these extracts are able to give electrons to active free radicals.

Total phenol content that measured using Folin-Ciocalteu method (Sponos and Wrolstad 1990) and the linear equation of the standard curve was $1 \mathrm{mg}$ of extract. The result of total 
phenolic content was calculated from the regression equation of the standard plot $(\mathrm{Y}=18.82 \mathrm{x}-$ 0.0844, $\mathrm{R}^{2}=0.9983$ ) (Fig. 1).

The total content of phenol for $L$. ledebourii Bioss extract obtained by the use of Freeze Dry and Oven Dry methods was $5.198 \pm 0.17$ and $1.814 \pm 0.05 \mathrm{mg}$ GAE/g DW of extract, respectively (Table 3). Increase in the density of phenolic compounds directly increases the capability of different extracts in trapping free radicals (Yong et al. 2009). The total content of phenolic compounds is not an exact and stable criterion to prove the high antioxidative power of a sample, but its nature, diversity, and the amount of phenol and flavonoid are main indexes to determine high anti oxidative power. L. ledebourii Bioss bulb, a native flower in Iran, has considerable amounts of phenol compounds in freeze dry method (5.198 mg/g of extract). This is much lower than that in L. concolor (389.76 $\mathrm{mg}$ in extract) reported by Jin et al. (2012). This indicates that phenolic compounds in L. ledebourii Bioss bulbs have very little activity. In all plants, antioxidative activity has a direct relationship to phenol and flavonoid levels. Mint (Mentha) extract has many phenol and flavonoid compounds and shows a good antioxidative activity (Sweetie et al. 2007). Rosemary (Rosmarinus officinalis L.) extract has high anti oxidative activity and this activity is in a close relationship with plants phenol content (Elmasta et al. 2006).

Table 3. Results of the non-enzyme test in L. ledebourii Bioss bulb explants.

\begin{tabular}{lllll}
\hline Drying method & $\begin{array}{l}\text { Flavonoid } \\
\mathrm{mg} \mathrm{RE} / \mathrm{g} \mathrm{DW}\end{array}$ & $\begin{array}{l}\text { FRAP } \\
\mu \mathrm{M} \mathrm{Fe} / \mathrm{g} \mathrm{DW}\end{array}$ & $\begin{array}{l}\mathrm{DPPH}\left(\mathrm{IC}_{50}\right) \\
\mathrm{mg} / \mathrm{ml}\end{array}$ & $\begin{array}{c}\text { Total Phenol } \\
\mathrm{mg} \mathrm{GAE} / \mathrm{g} \mathrm{DW}\end{array}$ \\
\hline Oven Dry & $0.02 \pm 0.42$ & $0.48 \pm 7.79$ & $0.97 \pm 11.27$ & $0.05 \pm 1.814$ \\
\hline Freeze Dry & $0.07 \pm 0.78$ & $1.47 \pm 25.88$ & $0.52 \pm 3.24$ & $0.17 \pm 5.198$ \\
\hline
\end{tabular}

FRAP = ferric reducing/antioxidant power and DPPH = 2,2-diphenyl-1-picrylhydrazyl

Iron III rehabilitee method is applied as a criterion for electron endowing ability of phenolic compositions. It forms an important mechanism in oxidation process of phenol composition. Electron endowing capacity (rehabilitating power) is related to the anti oxidative activity of biological compounds (Arabshani-Delouuee and Urooj 2007).

Existence of some secondary metabolites namely cardiac glycosides, tannin, saponin, steroids, alkaloids and terpenoid in the bulb of $L$. ledebourii Bioss. was ovserved. Presence of tannin activity was not observed (Table 4).

Table 4. Analysis of phytochemical compounds in L. ledebourii Bioss.

\begin{tabular}{ccccccc}
\hline Plant & Cardiac glycosides & Tannin & Saponin & Steroids & Alkaloids & Terpenoid \\
\hline L. ledebourii & $*$ & $*$ & $*$ & $*$ & $*$ \\
\hline
\end{tabular}

*= Plant secondary compounds.

Considering the results, the importance of this research and the importance of this domestic plant these kinds of investigations are crucial and valuable. Although these tests are the introductory identification of chemical components, but open the path to further researches where new techniques could be applied.

\section{Acknowledgments}

The Authors are thankful to the staffs and managers of Iranian Biological Resource Center for providing necessary facilities to conduct this study. 


\section{References}

Akinmoladun AC, Ibukun EO, Afor E, Obuotor EM and Farombi EO 2007. Phytochemical constituent and antioxidant activity of extract from the leaves of Ocimum gratissimum. Sci. Res. Essay 2: 163-166.

Arabshahi-delouee S and Urooj A 2007. Antioxidant properties of various solvent extracts of mulberry (Morus indica L.) leaves. Food Chem. 102: 1233-1240.

Asghari J and Mazaheri-tehrani M 2010. Extraction of tannin from Eucalyptus camaldulensis Dehnh and trimyristin from Myristica fragrans Houtt by using microwave irradiation. J. Medicinal Aromatic Plants 26(2): 185-195.

Azadi P 2003. Effect of growth regulators, sucrose concentration and scale pieces on micropropagation of Chelcheragh lily (Lilium ledebourii) in spring season. Proceedings of the 2nd Sci. and Applied Seminar on Ornament. Plants. p. 43

Azadi P and Khosh-Khui M 2007. Micropropagation of Llilium ledebourii (Baker) Bioss as affected by plant growth regulator, sucrose concentration, harvesting season and cold treatments. Electronic J. Biotech. 10(4): 582-591.

Benzie IFF and Strain JJ 1999. Ferric reducing/antioxidant power assay: direct measure of total antioxidant activity of biological fluids and modified version for simultaneous of total antioxidant power and ascorbic acid concentration. Methods in Enzymol. 299: 15-27.

Bernard D, Kwabena AI, Osei OD, Achel Daniel G, Achoribo Elom S and Sandra A 2014. The Effect of Different Drying Methods on the Phytochemicals and Radical Scavenging Activity of Ceylon Cinnamon (Cinnamomum zeylanicum) Plant Parts. European J. Medicinal Plants 4(11): 1324-1335.

Bouayed J, Hoffmann L and Bohn T 2011. Total phenolics, flavonoids, anthocyanins and antioxidant activity following simulated gastro-intestinal digestion and dialysis of apple varieties: Bioaccessibility and potential uptake. Food Chem. 128: 14-21.

Conforti F, Statti GA and Menichini F 2007. Chemical and biological variability of hot pepper fruits (Capsicum annuum var. acuminatum L.) in relation to maturitystage. Food Chem. 102: 1096-1104.

Dat J, Vandenabeele S, Vranová E, Van montagu M, Inzé D and Van breusegem F 2000. Dual action of active oxygen species during plant stress responses. Cell Mole Life Sci. 57: 779-795.

Deepa N, Kaura CH, Georgea B, Singhb B and Kapoor HC 2007. Antioxidant constituents in some sweet pepper (Capsicum annuum L.) genotyps during maturity. LWT Food Sci. Tech. 40: 121-129.

Dhindsa RS, Dhindsa PP and Thorpe TA 1980. Leaf senescence correlated with increased levels of membrane permeability and lipid-peroxidation and decreased levels of superoxide dismutase and catalase. J. Exp. Bot. 32: 93-101.

Edeoga HO, Okwu DE and Mbaebie BO 2005. Phytochemical Constituents of some Nigerian Medicinal Plants. African J. Biotech. 4(7): 685-688.

Elmastas M, Gülçin IIL DAK, Küfrevio LU, Bao lu K and Aboul-enein HY 2006. Radical scavenging activity and antioxidant capacity of Bay leaf extracts. J. Iran Chem. 3(3): 1258-266.

Fridovich L 1995. Superoxide radical and superoxide dismutases. Ann. Rev. Biochem, 64: 97-112 .

Gardner PT, White TAC, Mcphail DB and Duthie GC 2000. The relative contributions of vitamin C, carotenoids and phenolics to the antioxidant potential of fruit juices. Food Chem. 68: 471-474.

Hosu A, Cristea VM and Cimpoiu 2014. Analysis of total phenolic, flavonoids, anthocyanins and tannins content in Romanian red wines: Prediction of antioxidant activities and classification of wines using artificial neural networks. Food Chem. 150:113-118.

Jamshid M, Ahmadi HR, Rezazadeh SH, Fathi F and Mazanderani M 2010. Study on phenolicd and anioxidant activity of some selected plant of Mazandaran province. Medic Plant 9(34): 177-183.

Jimenez A, Hernandez JA, Del rio LA and Sevilla F 1997. Evidence for the presence of the ascorbateglutathione cycle in mitochondria and peroxisomes of pea leaves. Plant Physiol. 114: 275-284.

Jin L, Zhang Y, Yan L, Guo Y and Niu L 2012. Phenolic compounds and antioxidant activity of bulb extracts of six Lilium species native to China. Mole J. 17: 9361-9378. 
Jose M, Eristinaperez M and Gomez 1999. Antioxidant enzymes and human disease chemical biochemistry. Chemical Biochem. 32(8): 595-603.

Khalili MA and Ebrahimzadeh MA 2015. A review on antioxidants and some of their common evaluation methods. J. Mazandaran Univ. Med. Sci. 24(120): 188-208.

Krishnaiah D, Devi T, Bono A and Sarbatly R 2009. Studies on phytochemical constituents of six Malaysian medicinal plants. J. Medicinal Plants Res. 3(2):067-072.

Kumar Gupta A and Neelam M 2006. Hepatoprotective activity of aqueous ethanolic extract of chamomile capitula in paracetamol intoxicated albino rats. Amer. J. Pharmacol and Toxicol. 1(1): 17-20.

Kumaran A and Karunakaran RJ 2006. Antioxidant and free radical scavenging activity of an aqueous extract of Coleus aromaticus. Food Chem. 97: 109-114.

Maber P and Hanneken A 2005. Flavonoids protect retinal ganglion cells from oxidative stress-induced death. Investigative Ophthalmol Visual Sci. 46(12): 4796-4803.

Macheix JJ, Fleurient A and Billot J 1990. Phenolic compounds in fruit processing. In: Fruit Phenolic. CRC Press, Boca Raton, FL. pp. 295-342.

Mejia LA, Hudson E, Gonzalez, DE, Mejia E and Vasquez F 1988. Carotenoid content and vitamin A activity of some common cultivars of Mexican peppers (Capsicum annuum) as determined by HPLC. J. Food Sci. 53: 1448-1451.

Miliauskas G, Venskutonis PR and Vnbeek, TA 2004. Screening of radical scavenging activity of some medicinal and aromatic plant extracts. Food Chem. 85:231-237.

Mohsen SM and Ammar ASM 2009. Total phenolic contents and antioxidant activity of corn tassel extracts. Food Chem. 112: 595-598.

Padasht dahkaei MN 2005. The investigation of different methods for culturing and propagarion of Chelcheragh lily (Lilium ledebourii), native of Iran, and its introduction possibility as a new floricultural crop. Ph. D. Thesis, Islamic Azad University, Science and Research Unit, Tehran, Iran. pp. 120.

Parekh J and Chanda SV 2007. In vitro Antimicrobial activity and phytochemical analysis of some Indian medicinal plants. Turk. J. Biol. 31: 53-58.

Parida, AK and Das AB 2005. Salt tolerance and salinity effects on plants: A review. Ecotoxicol and Environmental Safety 60: 324-349.

Pellegrini N, Simonetti P, Gardana C, Brenna O, Brighenti F and Pietta PG 2000. Polyphenol content and total antioxidant activity of vini novelli (young red eines). J. Agri. Food Chem. 48: 732-735.

Polle A, Otter T and Seifert F 1994. Apoplastic peroxidases and lignification in needles of Norway spruce (Picea abies L.). Plant Physiol. 106: 53-60.

Rechinger KH. 1989. Flora Iranica, Liliaceae. Akademische Druck-u, Verlgsantalt, Graz, Austria. pp. 58-59.

Rigo A and Rotilio G 1977. Simultaneous determination of superoxide dismutase and catalase in biological materials by polarography. Ann. Rev. Biochem. 81: 157-166.

Rohi-Boroujeni H, Heidarian S, Rohi-Boroujeni H and Rafieian-Kopaei M. Phytochemical constituents of Moringa peregrina seeds, Der Pharma Chemica, 8(5):80-86

Sanchez-Moreno C, Larrauri JA and Saura-Calixto F 1998. A procedure to measure the antiradical efficiency of polyphenols. J. Sci. Food Agric. 76: 270-276.

Shukla SH, Mehta A, Bajpai VK and Shukla S 2009. In vitro antioxidant activity and total phenolic content of ethanolic leaf extract of Stevia rebaudiana Bert. Food Chem. Toxicol. 47: 2338-43.

Singh KBR, Malhotra S, Halila MH, Kinghts EJ and Verma MM 1994. Current status and future strategy in breeding chickpea for resistance to biotic and abiotic stresses. Euphytica 73: 137-149.

Sponos GA and Worlstad RE 1990. Influence of processing and storage o phenolic composition of Thompson seedless grape juice. J. Agric Food Chem. 38: 1565-1571.

Sun L, Zhang J, Lu X, Zhang L and Zhang Y. 2002. Evaluation to the antioxidant activity of total flavonoids extract from persimmon (Diospyros kaki L.) leaves. Food Chem. Toxicol. 49: 2689-2696.

Sweetie R, Ramesh CH and Arun SH 2007. Antioxidant potential of mint (Menthaspicata L.) in radiation processed lamb meat. Food Chem. 100(2): 451-458. 
Taiz L and Zeiger E. 2002. Plant Physiology, 3rd edition. pp. 690.

Velioglu YS, Mazza G, Gao L and Oomah BD 1998. Antioxidant activity and total phenolics in selected fruits, vegetables, and grain products. J. Agri. Food Chem. 46: 4113-4117.

Young kil H, Seong ES, Ghimire BK, Chung IM, Kwon SS, Goh EJ, Heo K, Kim MJ, Lim JD, Lee D and Yu CY. 2009. Antioxidant and antimicrobial activities of crude sorghum extract. Food Chem. 115: 1234-1239.

Zhou S, Ramanna, MS, Visser RGF and Van tuyl JM 2008. Analysis of the meiosis in the F1 hybrids of Longiflorum $\times$ Asiatic (LA) of lilies (Lilium) using genomic in situ hybridization. J. Genetics and Genom. 35: 687-695.

(Manuscript received on 12 April, 2018; revised on 2 June, 2018) 